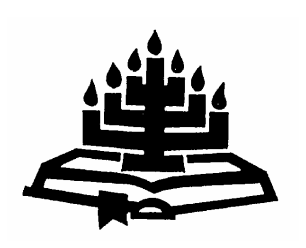

\title{
Waarderingswoord: Cassie Venter - kollega en geloofsvriend
}

'n Goeie getuigskrif vir Cassie Venter is die feit dat al die outeurs wat meegewerk het aan hierdie uitgawe wat aan hom opgedra is, entoesiasties en positief gereageer het om 'n artikel te skryf. Hierdie outeurs verteenwoordig kundiges in die vakgebied Praktiese Teologie - kollegas van ander universiteite asook sy Potchefstroomse kollegas wat met hom saamwerk in die Fakulteit Teologie. Daaruit kan afgelei word dat elkeen wat vir meer of minder jare met Cassie saamgewerk het, verryk is deur die erns en humor van 'n wonderlike kollega.

\section{Vormingsjare}

Casper Jan Hendrik Venter is op 26 Februarie 1940 in Postmasburg gebore as oudste kind van Casper en Annie Venter. Hy matrikuleer aan die Hoërskool Wessel Maree in Odendaalsrus. Self getuig hy dat hy as skoolkind en katkisant geslyp is deur proff. P.W. Buys en Benoon Duvenage wat albei predikante in dié gemeente was. Sy moeder leef nog en stel steeds op die rype ouderdom van 92 intens belang in Cassie se doen en late. Dwarsdeur sy lewe was daar 'n besondere verhouding tussen Cassie en sy ma en was sy fyn ingestel daarop om deur haar ma-wees vir haar kind net die beste te gee - ook in die gewoonste dinge. Maar sy kon die gewone ook op 'n ongewone manier doen. Omdat sy geweet het hoe 'n soettand Cassie is, het sy tydens sy studentejare vir sy verjaardag vir hom 'n sjokoladekoek gebak. 'n Geleentheid Potchefstoom toe was daar nie, maar om die soete geskenk betyds by sy bestemming te kry, het sy die sjokoladekoek netjies verpak en dit - ja let wel - per pos versend! Die resultaat? Die versiersel was effens beskadig, maar die soet smaak teen die verhemelte het moederliefde uitgespel. Cassie se moeder is reeds fluks op pad na 93 jaar en dit is vir Cassie 'n prioriteit en 'n ereplig om gereeld by haar te kom.

Hy skryf in 1958 by die PU vir $\mathrm{CHO}$ in en hierdie blootstelling aan die akademie en sy aktiewe deelname aan die studentelewe dra by tot sy vorming om later jare sy plek op verskeie terreine vol te staan. 
Sy leierseienskappe is gou raakgesien en hy dien as primarius van Heimat (1962 en 1963), asook as lid (1961) en Sekretaris van die Studenteraad (1963). Daarom ken en verstaan hy al die jare aan die Teologiese Skool die lief en leed van studente en help hy mee aan hulle vorming. Akademies vaar hy bo-gemiddeld en behaal sy B.A. met Latyn en Grieks (onderskeiding) in 1960. Verder ook die B.A.Hons. (Grieks met onderskeiding, 1962) en die Th.B. ook met onderskeiding (1964).

Cassie ontmoet vir Mariana Viljoen van Ficksburg in sy studentejare en sedert hulle huwelik in 1965 is hulle reeds vir veertig jaar 'n voorbeeldige huwelikspaar. Mariana is op vele gebiede deel van Cassie se lewe en met haar sterk persoonlikheid dra sy by daartoe dat hulle 'n enorme (Cassie se woord) paar in hulle omgewing is. Hulle ontvang twee pragtige kinders van die Here: Hanli (van Schalkwyk, getroud met Gerrit) en Cassie (jnr). Cassie jnr. is in 2000 in 'n motorongeluk oorlede en die wyse waarop hierdie ouerpaar in die geloof hulle pyn verwerk het, spreek boekdele van hulle geloof in die lewende God. Om oupa van Lisa-Mari te kon word, is vir Cassie 'n genadige geskenk van die Here en 'n vreugdevolle ervaring wat 'n glimlag permanent om sy mond laat plooi. Die Venters is 'n hegte familie wat graag saam vakansie hou en hulle het 'n wonderlike uitgebreide vriendekring deur al die jare opgebou.

\section{Produktief in die bediening}

Van jongs af het Cassie die begeerte gehad om predikant te word en hy het alles in die werk gestel om hierdie ideaal moontlik te maak. Hy het onder andere vir drie maande van elke studiejaar ondergronds in die myn op Allanridge gewerk. Hy vertel:

Hier het ek onder die medemynwerkers bekendgestaan as die 'siel mechanic'. Hierdie werksondervinding was ook 'n leerskool in die lewe - baie mensekennis en insig in menseverhoudings en ook die skeeftrekking daarin is op grond van hierdie interaksie met mense uit die myngemeenskap opgedoen. As toeskouer en waarnemer kon ek sien hoe verhoudings en die koers van jou lewe dikwels bepaal word deur die keuses - reg én verkeerd - wat jy maak.

Die ondervinding in die myn het ook daartoe bygedra dat ek Fanakalo geleer het - hierdie myntaal het indirek 'n toegangskanaal tot die gesprekke van swart mynwerkers geword. Taal bly 'n sonderlinge oorbruggingsfaktor - praat met 'n swart mynwerker in die taal wat hy verstaan, dan blink sy gesig en oë en glimlag hy breed! Om vir drie maande per jaar ondergronds in 'n myn te werk, impliseer ook dat jy merendeels 
in die geselskap van swart mynwerkers was. Dikwels voel jy alleen, half vies vir die hitte en jou pap toebroodjie, die geskarrel van die rotte in die myngange, lus om tog 'n bietjie te gesels. Maar omdat my eie woordeskat van die swart mynwerkers se taal ook maar beperk was, het dit tog die gespreksonderwerpe effens gerem en was die geselsies net op die oppervlakte - onbevredigend as ' $n$ mens juis wou probeer kommunikeer!

En werk jy in die myn, is die kanse goed dat jy ook Kersfees werk. Maar hierdie oortyd beteken ook driedubbele betaling! En jy trek op so 'n feesdag maar jou mynklere aan om te verseker dat studieskuld nooit jou baas word nie, maar ai, die besef dat jou mense bogronds 'n Kersete eet, aansit by 'n bak koekstruif ...!

$\mathrm{Na}$ die voltooiing van sy studies het die Venters in uiteenlopende en geografies verspreide gemeentes gewerk, nogeens 'n bewys van die gebalanseerde vorming van hierdie dominee. Hy bedien agtereenvolgens Laeveld (Tzaneen), Koster, Meyerspark in Pretoria en Stellenbosch. In Meyerspark doen hy die grondwerk vir 'n lewendige en toegewyde gemeente en beleef die genade dat hy as 'n hoogtepunt in sy bediening op Stellenbosch kan werk. Tydens sy bedieningstyd in Stellenbosch het hy op versoek van U.S. se Fakulteit Teologie vir 'n paar jaar modules in herderlike sorg vir M.Th.-studente aangebied. Sy bedieningstyd in Stellenbosch was eiesoortig - 'n klein gemeentetjie - aanvanklik ver verspreid: Stellenbosch, Strand, Hermanus, Caledon, Grabouw, Gansbaai, Bredasdorp. Maar hierdie geografiese uitgestrektheid het die bonus gehad dat hy en Mariana die Boland op baie ongewone paaie kon verken. In Stellenbosch was hulle bevoorreg om eintlik ingesluit te wees in twéé kerkgemeenskappe.

In die NG-wyk waarin ons gewoon het, het die NG-ouderling sommer altyd heel eerste vir ons kom sê watter aand ons moet oophou vir 'n byeenkoms. Toe ons Noorde toe verhuis het, het hierdie NG-wyk ook 'amptelik' van ons afskeid geneem - wat 'n heerlike voorreg van kerklike broederskap en koinonia.

Cassie en Mariana hou steeds kontak met baie lidmate van hulle vorige gemeentes, want een van Cassie se sterk eienskappe is die bou en instandhou van sterk verhoudinge. Sy loopbaan kan amper in twee gelyke dele van twintig jaar elk verdeel word: twintig jaar predikant en net meer as twintig jaar professor aan die Teologiese Skool op Potchefstroom (TSP). 


\section{Gewilde professor aan die TSP en Fakulteit}

In 1985 begin sy werksaamhede by die TSP en Potchefstroomse Universiteit vir Christelike Hoër Onderwys. Hy het deur die jare 'n besondere band met studente ontwikkel, ook omdat hy met elkeen persoonlike kontak het tydens hulle preekmaakproses. Hy ken elkeen baie persoonlik en het talle pastorale gesprekke met hulle gehad. Daar was selfs studente met wie hy indringende gesprekke met die oog op hulle huwelike gehad het. Vir die meeste was hy 'n vaderfiguur. Cassie is 'n skitterende dosent, logies in die aanbieding van klasse en wyd belese. Die bewys dat die studente sy klasse baie leersaam gevind het, is die talle nagraadse studente wat onder sy leiding verder studeer het. Hy is toeganklik vir studente en hulle waardeer sy wonderlike humorsin.

Hy het 'n geweldige ('n enorme?) aantal preekkolleges hanteer en na baie studente se optredes in gemeentes gaan luister. Vir 'n tyd lank het hy alleen die doseerwerk in die vakgroep Praktiese Teologie hanteer en tegelyk in Homiletiek, Pastoraal en Kategetiek klas gegee en al die preekbegeleiding van studente waargeneem. Hieruit blyk dat Cassie 'n harde werker is en ook 'n goeie bestuurder as Vakhoof en lid van die UK/Dagbestuur van die Senaat van die TSP en die Fakulteit Teologie is. Cassie is ' $n$ baanbreker by die TSP/Fakulteit Teologie op die vakgebiede Pastoraal en Homiletiek. $\mathrm{Hy}$ is en bly egter primêr 'n pastor - nie alleen vir die studente nie, maar ook vir die administratiewe personeel en sy kollegas. Op die Skooltjie is sy liefde vir God, sy medemense en almal verbonde aan die TSP en Fakulteit sy uitstaande kenmerk.

\section{Akademiese loopbaan}

Cassie het in die amper 21 jaar as dosent en akademikus 'n begenadigde loopbaan gehad. Hy behaal in 1972 'n Th.M. oor die onderwerp "Die pastorale dimensie in die begeleiding van sterwendes". In 1974 promoveer hy met 'n Th.D. in Praktiese Teologie ("Die bediening van die versoening aan die bejaarde. 'n Pastorale studie in die lig van die Pastorale Briewe") en voltooi in 1985 'n tweede Th.D. in Nuwe Testament oor die onderwerp "Die Pauliniese paranese in Romeine 12:1-15:13 - 'n eksegetiese studie".

Sy spesialiseringsgebiede is homilitiek, pastorale versorging en kategetiek. In die Suid-Afrikaanse konteks het hy deurslaggewende bydraes op die gebied van bejaardesorg (pastoraal), verklarende 
prediking (Homiletiek) en diakoniek gelewer (vgl. sy publikasie Uitkringende liefdesbetoon).

Verbandhoudende sake wat in die 48 navorsingsartikels en 23 ander wetenskaplike bydraes wat hy geskryf het na vore kom, is onder andere die volgende: die prakties-teologiese grondslae van die prediking, die proses van preekmaakkunde, kommunikatiewe aspekte in die prediking, die toerusting van die gemeente en die aanwend van gawes, die spirituele ingesteldheid van die prediker, die brugbouproses van die teks van die Bybel en daarvandaan na die teks van die lewe, diakonia in sy vele gestaltes, die diens van versoening, die verband tussen geestelike groei en emosionele intelligensie. In hierdie artikels kom sy skerp insig na vore, gekombineer met netjiese tegniese afronding, waarin die stylvolle hand van Mariana gesien kan word. Gedurende sy twintigste jaar aan die TSP/Fakulteit het hy nie minder nie as tien artikels vir wetenskaplike tydskrifte geskryf en almal is na deeglike keuring aanvaar vir plasing.

Onder sy leiding is 14 Th.D.-proefskrifte en 23 Th.M.-grade oor 'n verskeidenheid onderwerpe voltooi, onder andere oor praktiesteoretiese grondslae van die vakgebied Diakoniologie/Praktiese Teologie. As eksaminator was hy betrokke by die evaluering van tientalle M.-verhandelings en D.-proefskrifte van verskillende universiteite. Hy was ook die skrywer/redakteur van 'n aantal boeke, onder andere By die sterfbed (1976); God bou op deur sy Woord (1988); Uitkringende liefdesbetoon (1996). Hy het ook vir die kerklidmaat in populêre kerklike tydskrifte 'n groot aantal artikels geskryf. Uitkringende liefdesbetoon is eintlik baie tiperend van die persoon van Cassie en sy liefde vir die teologiese wetenskap. Hy skryf onder andere in sy voorwoord:

Die titel is ontleen aan Romeine 12:9-21 waarin as 't ware drie sirkels van liefdesbetoon na vore kom, naamlik in die kring van gelowiges, aan alle mense en uiteindelik ook as kos en water aan 'n vyand ... die opdrag tot kommunikatiewe handelinge in die liefdesgemeenskap in die kerk en vandaar as uitkringende liefdesbetoon is onontkombaar. En die verlange daarna is groot by baie.

C.J.H. Venter se teologie word gekenmerk deur sy Skrifgebonde uitgangspunte waarin hy hom volledig aan die gesag van die Skrif onderwerp. Dit kombineer hy deur die Woord in die werklikheid te laat grondvat, soos hy dit telkens uitdruk: "Praktiese Teologie moet hande en voete in die gemeente kry." 
Hy dien op verskillende vakverenigings: As lid (1972 tot tans) en sekretaris (1973-1975) van die Gereformeerde Teologiese Vereniging (GTV-Hoofbestuur); Die Werkgemeenskap vir Praktiese Teologie in Suid-Afrika (lid sedert 1971, Ondervoorsitter van 1983 tot 1984 en weer van 1992 tot 1998, Voorsitter van 1998 tot 2001); Nuwe-Testamentiese Werkgemeenskap van Suid-Afrika (lid vanaf 1973 en Assessorlid vanaf 1977). Hy is ook lid van die SuidAfrikaanse Akademie vir Wetenskap en Kuns. Cassie het verskeie voordragte by internasionale en nasionale kongresse gelewer en in Nederland en Korea as gasdosent opgetree. Die feit dat soveel Koreaanse predikante onder sy leiding doktorsgrade verwerf het, het bygedra daartoe dat 'n stewige gereformeerde teologie, veral op die gebied van die Homiletiek, in Korea beslag gekry het.

\section{Ons vriend Cassie}

By uitnemendheid is Cassie 'n geloofsviend vir baie uit verskillende gebiede van die samelewing. Hy kan dit wees, omdat hy kind van die Here bly, nederig en een wat uit genade leef. 'n Gewilde prediker, iemand wat oor die land gereis het om kursusse aan te bied: toerusting vir ouderlinge, diakens, gemeentes, jeuggroepe, ensovoorts. In sy eie gemeente: 'n betrokke lidmaat. Hy leef met 'n passie vir sy gesin en familiekring en die wyse waarop hy en Mariana met liefde vir mekaar saamleef, is ' $n$ inspirasie vir ander egpare. Hy is 'n lekker pa en oupa, altyd lojaal teenoor ander. As 'n positiewe mens vol geloof hoop en liefde werk hy steeds met ywer in die Koninkryk van God.

\section{B.J. (Ben) de Klerk}

